\title{
A new cyanobacterial species of Anabaena genus (Nostocales, Cyanobacteria) from Bulgaria
}

\author{
Ivan Kirilov Kirjakov ${ }^{1} \&$ Katya Naneva Velichkova ${ }^{2}$ \\ 1 Department of Botany, Paisiy Hilendarski University of Plovdiv, 24 Tsar Assen St., 4000, Plovdiv, Bulgaria. \\ 2 Department of Biology and aquaculture, Agricultural Faculty, Trakia University, Students Campus, 6000 Stara Zagora, \\ Bulgaria.
}

\section{Resumen}

\section{Correspondence}

K.N. Velichkova

E-mail: genova@abv.bg

Received: 8 January 2016

Accepted: 29 April 2016

Published on-line: 17 May 2016

\begin{abstract}
Una nueva especie de cianobacteria del género Anabaena (Nostocales, Cyanobacteria) de Bulgaria
\end{abstract}

Se describe una nueva especie del género de Cyanobacterias, Anabaena Bory ex Born. et Flah. (Nostocales) de las montañas Ródope de Bulgaria. Anabaena rhodopensis sp. nova. tiene acinetas con paredes celulares esculpidas. Se dan los datos biométricos para el tamaño de las células vegetativas, heterocistos y acinetos.

Palabras clave: Anabaena, Evaluación biométrica, Bulgaria, Cyanobacteria, Nueva especie.

\begin{abstract}
A new species of cyanobacterial genus Anabaena Bory ex Born. et Flah. (Nostocales) from Rhodope Mountains in Bulgaria is described. Anabaena rhodopensis sp. nova. has akinetes with sculptured cell walls. Biometrical data for size of vegetative cells, heterocytes and akinetes are given.
\end{abstract}

Key words: Anabaena, Biometric evaluation, Bulgaria, Cyanobacteria, new species.

\section{Introduction}

The cyanobacterial genus Anabaena Bory ex Born. et Flah. 1888 contains several morphologically different clusters (Komárek \& Zapomělová 2007). More than 100 species have been described within the cyanobacterial genus Anabaena (Hollerbach et al. 1953, Desikachary 1959, Starmach 1966, Kondrateva 1968, Guiry \& Guiry 2014). Thirty one species of the traditional Anabaena with apoheterocytically developing akinetes are separated by Komarek \& Anagnostidis (1989) in the genus Trichormus (Ralfs ex Born. et Flah.) Kom. et Anagn.

The systematic classification of Cyanobacteria has changed significantly during the last decades. The modern classification of cyanoprokaryotes is based on a combined assessment of morphological and molecular analyses (Komárek 2012). The morphological description of specimens from natural populations is very important for determining phenotypic variations and studying the ecology of a specific type.

Different morphological changes of cyanobacterial strains can be observed early after their isolation (Komárek \& Zapomělová 2008). The morphological studies depend on the samples directly collected from the field. The shape and size of vegetative cells and akinetes as well as the relative location of akinetes to heterocytes are impor- 
tant for distinguishing Anabaena species (Tuji \& Niiyama 2010).

The aim of this study was the description of the morphological and ecological characteristics of a newly found Anabaena species from Bulgaria.

\section{Material and methods}

Our material was collected on $25-\mathrm{V}-2010$, in the central region of Rhodope Mountains, near the Madan town, Bulgaria (41 ${ }^{\circ} 48^{\prime} 209^{\prime \prime} \mathrm{N}, 24^{\circ} 93^{\prime} 358^{\prime \prime}$ E). The locality was a rock from which water constantly trickles. The altitude of the locality was over 800 AMSL. Morphological observations such as the shape and dimensions of vegetative cells, heterocytes, akinetes as well as the location of akinetes to heterocytes were conducted under light microscope Olympus CX31 in the Department of Biology and Aquaculture at the Trakia University. The population was statistically described for size of vegetative cells, heterocytes and akinetes in filaments $(n=50)$.

\section{Description}

\section{Anabaena rhodopensis sp. nova.}

Trichomes solitary, straight or somewhat curved. Vegetative cells cylindrical with rounded edges without gas-vacuoles, blue green 4.4-5.1-5.7 $\mu \mathrm{m}$ wide, and 3.3-4.6-6.4 $\mu \mathrm{m}$ long (Table 1). Heterocytes spherical 5.0-6.2-7.2 $\mu \mathrm{m}$ in diameter $(\mathrm{n}=50)$. Akinetes solitary or in groups of 2 , not adjacent to heterocytes. They were cylindrical with parallel or very slightly swollen walls and rounded edges 7.7-9.8-12.2 $\mu \mathrm{m}$ wide and 19.8-28.6-37.6 $\mu \mathrm{m}$ long. The akinete wall was yellowish. The exospores were covered with coarse verrucae, which were rectangular in cross section and with irregular contours when observed from above. Verrucae were 0.6-1.1 $\mu \mathrm{m}$ high (Fig. 1).
Ecology: together with Tribonema Derbès \& Solier, Cosmarium Corda, Bacillariophyta in fur on a rock stone down which water constantly trickles, Rhodope Mountains, Madan town, May 252010. pH 6.9, Temperature $-20{ }^{\circ} \mathrm{C}$.

Type locality: Rhodope Mountains, Madan town, Bulgaria.

Iconotype: Shown in figure 1.

Etymology: This species was named after the region of its occurrence-Rhodope Mountains, Bulgaria.

\section{Diagnosis}

Trichoma recta aut leviter circumflexa. Cellulae vegetativae cylindricae, usque breviter cylindricae cum extremitatibus rotundatis, sine plenis aere vacuoles, caeruleo viridi, 4.4-5.1-5.7 $\mu \mathrm{m}$ latae et 3.3-4.6-6.4 $\mu \mathrm{m}$ longae. Heterocytae sphaericae, 5.0-6.2-7.2 $\mu \mathrm{m}$ diametro. Sporae elongatecylindricae cum parietibus parallelis aut leviter inflates et angulis obtusis. Tunica earum pallid flava. Exosporum cum verrucis rudibus quae in sectione in longitudinam rectangulare, sed in sectione transversa cum confiniis irregularibus, 0.6-1.1 $\mu \mathrm{m}$ latae et $0.8-1.5 \mu \mathrm{m}$ aitae. Sporae singulae aut raro binae, non ligatae cum heterocytis, 7.7-9.8-12.2 $\mu \mathrm{m}$ latae et 19.8-28.6-37.6 $\mu \mathrm{m}$ longae.

Habitatio-locus classicus: simui cum Tribonema, Cosmarium, Bacillariophyta in tegumento saxa aqua fluente continenter. Montes Rhodope, propre Madan, Bulgaria, Anno 2010, 25 Majo.

Iconotypus: Figura nostra 1.

\section{Remarks}

The newly found species from Bulgaria had characteristic sculpture on the akinete exospores. The sculpture on akinete wall is considered to be a good feature of Anabaena species (Elenkin 1938, Bourrelly 1970). The existence of sculptures is a rarity in the genus. The species this genus having

\begin{tabular}{|l|c|c|c|c|c|}
\hline \multirow{2}{*}{ Anabaena rhodopensis $(\mathrm{n}=50)$} & \multicolumn{2}{|c|}{ Vegetative cells } & \multicolumn{2}{c|}{ Akinetes } & Heterocytes \\
\cline { 2 - 6 } & Length & Width & Length & Width & Diameter \\
\hline $\min$ & 3.3 & 4.4 & 19.8 & 7.7 & 5.0 \\
\hline $\max$ & 6.4 & 5.7 & 37.6 & 12.2 & 7.2 \\
\hline $\mathrm{x} \pm \mathrm{m}_{\mathrm{x}}$ (arithmetic mean value) & $4.6 \pm 0.3$ & $5.1 \pm 0.1$ & $28.6 \pm 0.4$ & $9.8 \pm 0.4$ & $6.2 \pm 0.2$ \\
\hline$\sigma \pm \mathrm{m}_{\sigma}$ (root mean square) & $2.0 \pm 0.2$ & $0.9 \pm 0.1$ & $13.5 \pm 1.0$ & $3.7 \pm 0.3$ & $1.3 \pm 0.1$ \\
\hline $\mathrm{V} \pm \mathrm{m}_{\mathrm{v}}$ (coefficient of variation) & $43.5 \pm 4.4$ & $1.8 \pm 0.2$ & $47.2 \pm 3.3$ & $37.8 \pm 2.7$ & $20.9 \pm 2.1$ \\
\hline
\end{tabular}

Tabla 1. Características biométricas de Anabaena rhodopensis sp. nova $(\mathrm{n}=50)$.

Table 1. Biometrical characteristics for Anabaena rhodopensis sp. nova $(\mathrm{n}=50)$. 
akinetes with different sculptured wall are Anabaena verrucosa B. Peters. and its f. major Kosinsk., Anabaena tatarica Kosinsk. (Kondrateva 1968), Anabaena batophora Frémy, Anabaena aspera Frémy, Anabaena fuellebornii Scmidle (Geitler 1932) and Anabaena echinospora Skuja (Elenkin 1938) (Table 2).

The species $A$. verrucosa, A. batophora and $A$. aspera are the closest to the newly found Anabaena sp. from Bulgaria by the sculptured wall. The species described here differed distinctly from all three species mentioned above (Table 2). A. rhodopensis sp. nova. had spherical heterocytes and sculptural formations at the akinete surface, which were rectangular in cross section and with irregular contours (Fig. 4). A.

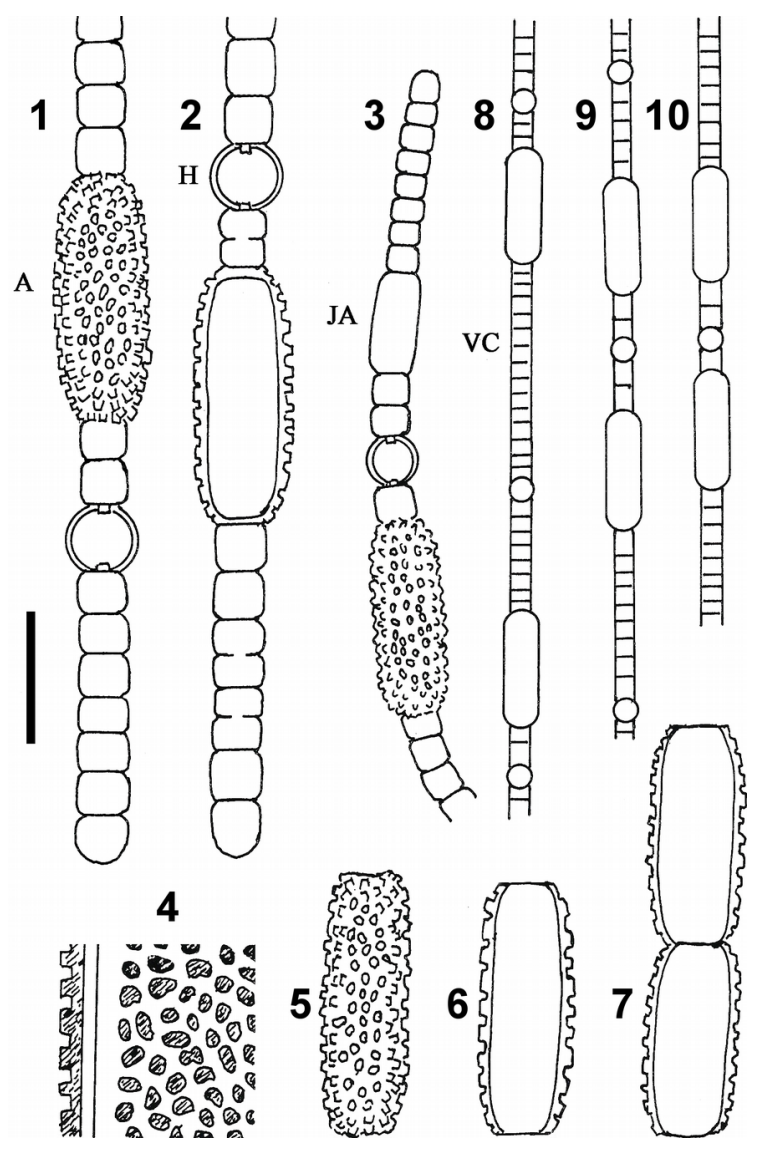

Figura 1. Anabaena rhodopensis sp. nova. 1-3: Tricomas con teterocitos $(\mathrm{H})$, acinetos viejos (A) y jóvenes (JA); 4: Detalle de la vaina y ornamentación de la pared celular de los acinetos; 5-7: Acinetos viejos. 8-10: Ejemplos (esquemas) de los principales tipos estructurales de heterocistos $(\mathrm{H})$, acinetos $(\mathrm{A})$ y células vegetativas (VC). Barra de escala $=5 \mu \mathrm{m}$.

Figure 1. Anabaena rhodopensis sp. nova. 1-3: Trichomes with heterocytes $(\mathrm{H})$, old akinetes (A) and young akinetes (JA); 4: Detail of sheath and sculpture cell wall of akinetes; 5-7: Old akinetes; 8-10: Examples (schemes) of main types trichome structure-heterocytes $(\mathrm{H})$, akinetes (A) and vegetative cells (VC). Scale bar $=5 \mu \mathrm{m}$ batophora is characterized particularly by cylindrical or ellipsoidal heterocytes and triangular papillae on akinetes. The heterocytes are cylindrical and the akinetes are with broadly triangular papillae in A. aspera. A. verrucosa and f. major differ clearly from the mentioned species by their cylindrical heterocytes and their narrow trichomes and akinetes.

It should be noted that the sculptural formation occured only in fully mature akinetes since the very young akinetes have smooth walls. As the size of the akinetes increased, a certain roughness appeared. Akinetes of different ages could be seen on one and the same filament.

\section{References}

Bourrelly P. 1970. Les algues d'eau douce. III. Paris.

Desikachary T. 1959. Cyanophyta. ICAR Monographs on Algae: New Delhi.

Elenkin A. 1938. Monographia algarum cyanophycearum aquidulcium et tarrestrium in finibus URSS inventarum (Sinezelenye vodorasli SSSR). MoscowLeningrad.

Guiry M \& Guiry G. 2014. Algae Base. World-wide electronic publication, National University of Ireland, Galway. Available at http://www.algaebase.org/search/ genus/detail/?genus_id=43086 (accessed on 11-I2015).

Geitler L. 1932. Cyanophyceae. In: Kryptogamen-Flora von Deutschland, Österreich und der Schweiz. Ed. 2. (Rabenhorst, L. Eds) Vol. 14, Leipzig. pp. 6731196.

Hollerbach M, Kosinskaja E \& Poljanski V. 1953. Bluegreen algae. Opredelitel presnovodnich vodoroslej SSSR 2: Moscow.

Komárek J. 2012. Nomenclatural changes in heterocytous Cyanoprokaryotes (Cyanobacteria, Cyanophytes). Fottea 12(1): 141-148.

Komárek J \& Anagnostidis K. 1989. Modern approach to the classification system of Cyanophytes 4-Nostocales. Algological Studies 56: 247-345.

Komárek J \& Zapomělová E. 2007. Planktic morphospecies of the cyanobacterial genus Anabaena = subg. Dolichospermum-1. part: coiled types. Fottea 7: 1-31.

Komárek J \& Zapomělová E. 2008. Planktic morphospecies of the cyanobacterial genus Anabaena = subg. Dolichospermum-2. part: straight types. Fottea 8(1): 1-14.

Kondrateva N. 1968. Blue-green algae-Cyanophyta. Viznacn. Prisnov. Vodorost. Ukr. RSR 1, 2: Kiev.

Starmach K. 1966. Cyanophyta-sinice. Flora slodkow. Polski 2: Warszawa.

Tuji A \& Niiyama Y. 2010. Phylogenetic Study by the Morphological and Molecular Analyses of Japanese Planktonic Anabaena Species. Bulletin of the National Museum of Nature and Science. Series B, 36(2): 71-80. 


\begin{tabular}{|c|c|c|c|c|c|c|c|c|c|}
\hline 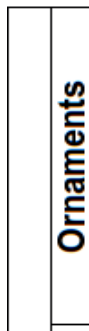 & 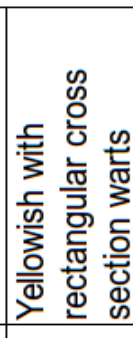 & 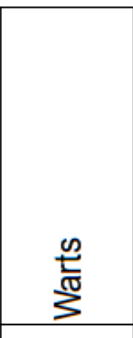 & 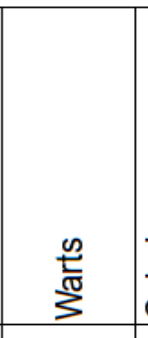 & 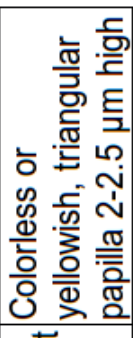 & 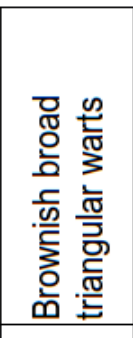 & 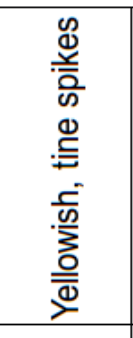 & 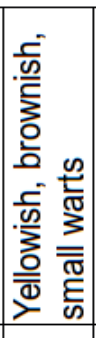 & 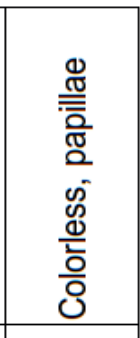 & \multirow{2}{*}{ 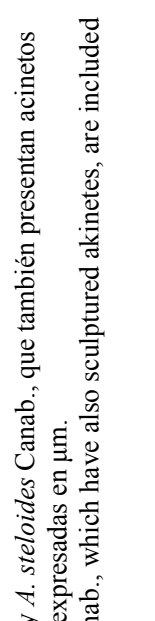 } \\
\hline 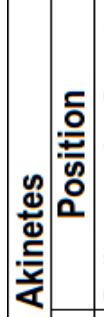 & 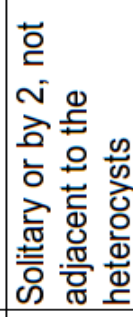 & 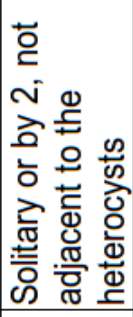 & 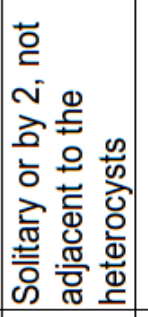 & 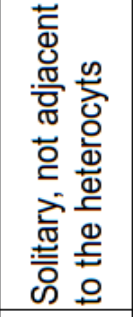 & 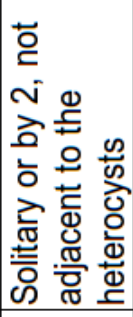 & 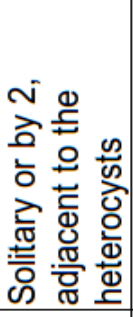 & 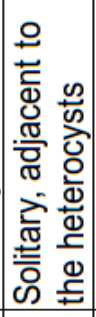 & 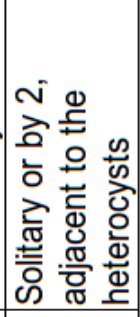 & \\
\hline 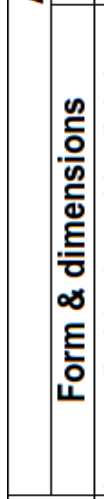 & 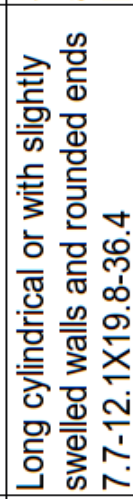 & 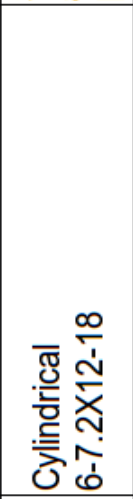 & 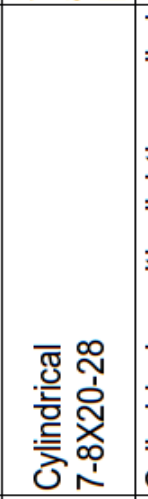 & 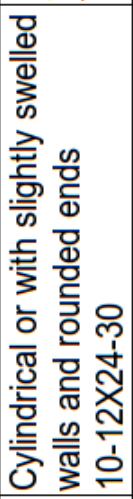 & 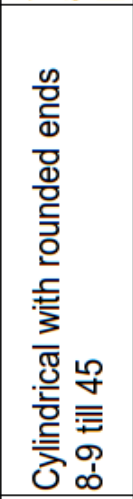 & 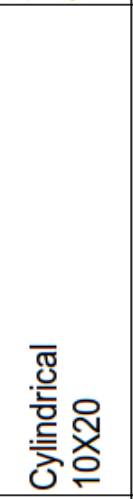 & 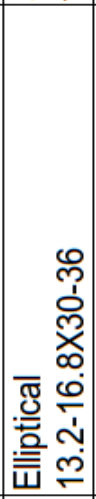 & 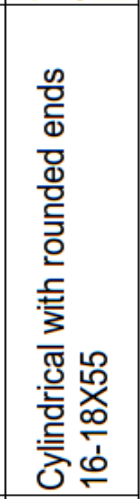 & శี \\
\hline 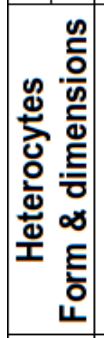 & 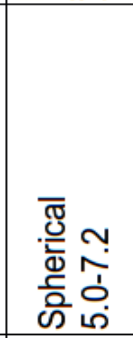 & 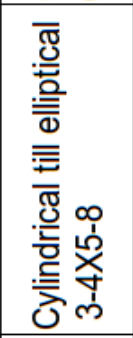 & 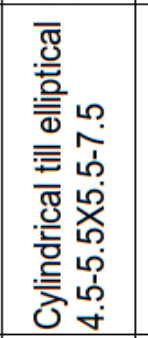 & 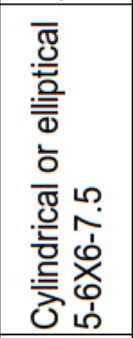 & 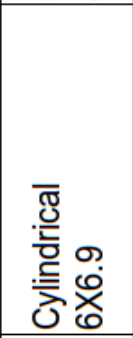 & 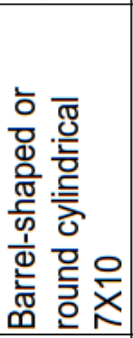 & 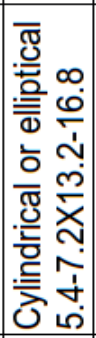 & 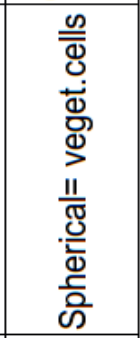 & \\
\hline 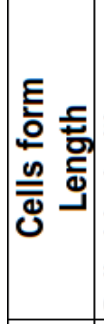 & 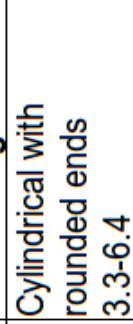 & 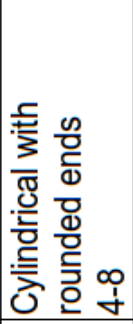 & 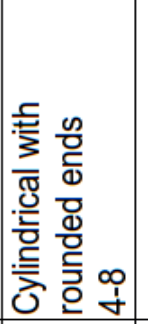 & 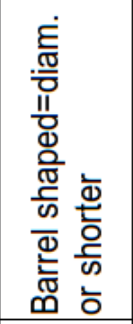 & 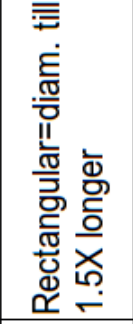 & 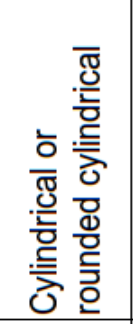 & 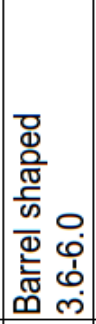 & 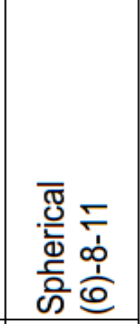 & \\
\hline 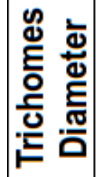 & $\begin{array}{l}\hat{L} \\
\dot{f} \\
\dot{y} \\
\dot{y}\end{array}$ & 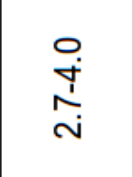 & $\begin{array}{l}n \\
\dot{f}\end{array}$ & L & 50 & م & 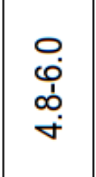 & $\underset{\dot{\theta}}{\check{1}}$ & \\
\hline $\begin{array}{l}\frac{\pi}{0} \\
\frac{\mathbb{2}}{0}\end{array}$ & 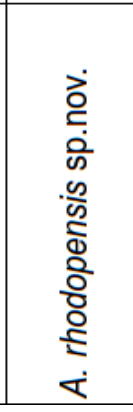 & 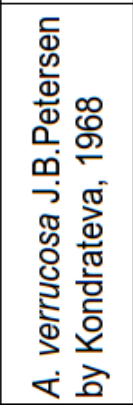 & 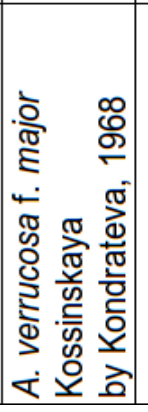 & 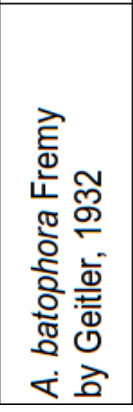 & 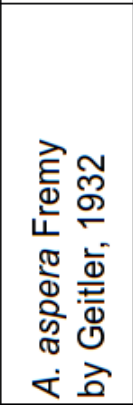 & 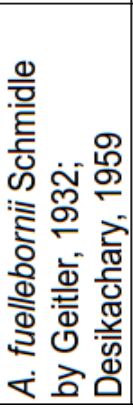 & 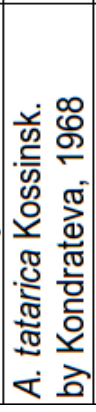 & 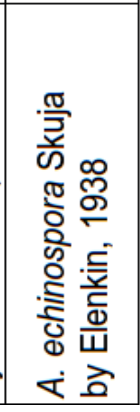 & \\
\hline
\end{tabular}

